\title{
IbM PKK Desa Payungan Dalam Memanfaatkan Sayuran Menjadi Bakso Yang Bernilai Gizi Tinggi
}

\author{
Ika Silfiana Arifatul Khoiriyah ${ }^{1 *}$, Dyah Kartika Wening ${ }^{2}$
}

1,2, Universitas Ngudi Waluyo

\section{A R T I C L E I N F O}

Article history:

Received 15 March 2018

Received in revised form 10 May 2018

Accepted 30 June2018

Available online 29 August 2018

\section{Kata Kunci:}

Budidaya rumpu laut, pendampingan masyarakat, Sapeken

Keywords:

Seaweed cultivation, community assistance, Sapeken

\begin{abstract}
A B S T R A K
Kegiatan pengabdian kepada masyarakat di PPK Desa Payungan ditujukan untuk pelatihan pemanfaatan sayuran menjadi bakso yang bernilai gizi tinggi dari lbM ini berjumlah 29 kader PKK Desa Payungan. Tujuan pengabdian ini yaitu memperkenalkan pemanfaatan sayuran menjadi bakso yang bernilai gizi tinggi, meningkatkan keikutsertaan masyarakat dalam mendukung program pola hidup sehat, merangsang kreativitas masyarakat untuk menghasilkan sesuatu yang bermanfaat, dan meningkatkan daya keterampilan masyarakat dalam berwirausaha. Lokasi pengabdian akan dilaksanakan di Desa Payungan Kecamatan Kaliwungu Kabupaten Semarang, melalui praktek demonstratif langsung yang melibatkan unsur-unsur pemangku kepentingan yakni PKK Desa Payungan Kecamatan Kaliwungu Kabupaten Semarang. Metode yang digunakan adalah Metode Training of Trainner (TOT) dengan cara pemberian materi melalui ceramah, kemudian dilanjutkan dengan praktik langsung oleh masing-masing peserta. Kegiatan pengabdian kepada masyarakat melalui skim Hibah Iptek bagi Masyarakat sumber dana LP2M tahun 2017 yang hasilnya berupa pelatihan untuk kegiatan IbM di Mitra PKK Desa Payungan Kecamatan Kaliwungu Kabupaten Semarang. Dalam kegiatan pelatihan IbM ini dihadiri anggota di Mitra PKK Desa Payungan Kecamatan Kaliwungu Kabupaten Semarang yang diikuti dengan antusias sampai acara selesai dan termotivasi untuk memproduksi sendiri.
\end{abstract}

A B S T R A C T

The community service activities in Payungan Desa PPK are aimed at training the use of vegetables to become high nutritional value meatballs from IbM, totaling 29 PKK Village cadres. The purpose of this service is to introduce the use of vegetables into high-nutritional meatballs, increase community participation in supporting healthy lifestyle programs, stimulate people's creativity to produce something useful, and increase the community's skills in entrepreneurship. The location of dedication will be held in Payungan Village, Kaliwungu Subdistrict, Semarang Regency, through direct demonstrative practices involving stakeholders, namely PKK Payungan Village, Kaliwungu District, Semarang Regency. The method used is the Training of Trainner (TOT) method by giving material through lectures, then followed by direct practice by each participant. Diversification of food ingredients from meat to vegetables is expected to be a pattern of eating vegetables for the people of Payungan Village. Community service activities through the Science and Technology Grants scheme for the Community source of LP2M funds in 2017, the results of which are training for IbM activities at PKK Partners in Payungan Village, Kaliwungu District, Semarang Regency. In this IbM training activity, members of Mitra PKK in Payungan Village, Kaliwungu District, Semarang District were attended enthusiastically until the event was finished and motivated to produce their own.

\footnotetext{
* Corresponding author.

E-mail addresses: ikasilfiana@gmail.com (Ika Silfiana Arifatul Khoiriyah)
} 


\section{Pendahuluan}

Salah satu olahan makanan berbahan dasar daging adalah bakso. Bakso sudah dikenal masyarakat Indonesia sejak lama, Jumlah peminatnya pun dari segala kalangan mulai dari anak-anak hingga orang dewasa. Minat masyarakat yang besar terhadap bakso mendorong kami untuk membuat varian bakso yang tidak berbahan dasar daging melainkan berbahan dasar sayuran. Kami memilih sayuran sebagai bahan dasar pembuatan bakso karena pada umumnya masyarakat tidak terlalu sering mengonsumsi sayur-sayuran. Sayuran sendiri memiliki kandungan gizi tinggi, khususnya kandungan vitamin dan mineral yang sangat dibutuhkan tubuh manusia untuk proses metabolisme tubuh. Kami telah melakukan survei di daerah Desa Payungan Kecamatan Kaliwungu Kabupaten Semarang yaitu dengan menggunakan 87 sampel orang warga dengan data sebagai berikut.

Tabel 1. Data peminat bakso di Desa Payungan

\begin{tabular}{lllll}
\hline No. & Pertanyaan & Ya & Tidak & Jumlah \\
\hline 1. & Apakah anda suka makan bakso? & 73 & 14 & 87 \\
2. & Apakah anda sering makan bakso? & 29 & 58 & 87 \\
3. & $\begin{array}{l}\text { Apakah anda pernah makan bakso yang } \\
\text { berisi selain bola daging? }\end{array}$ & 20 & 67 & 87 \\
4. & $\begin{array}{l}\text { Apakah anda pernah makan bakso yang } \\
\text { terbuat dari sayuran? }\end{array}$ & 15 & 72 & 87 \\
5. & $\begin{array}{l}\text { Jika ada bakso yang terbuat dari sayuran } \\
\text { apakah anda berminat mencobanya? }\end{array}$ & 76 & 11 & 87 \\
\hline
\end{tabular}

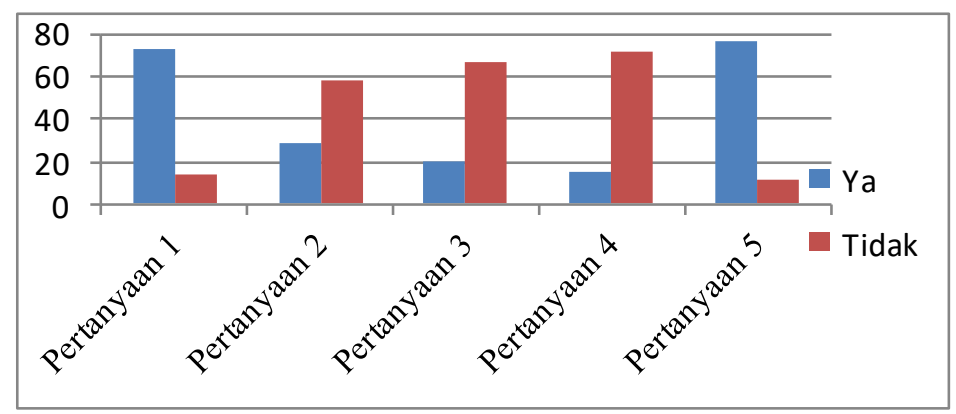

Grafik 1. Peminat bakso di Desa Payungan

Berdasarkan data pada Table 1 terlihat bahwa besarnya peminat bakso di Desa Payungan yaitu sebanyak 73 orang warga. Warga yang belum pernah makan bakso yang terbuat dari sayuran sebanyak 72 orang warga dan warga yang berminat mencoba bakso yang terbuat dari sayuran sebanyak 76 orang warga. Berdasarkan hasil survei ini kami yakin bahwa bakso yang terbuat dari sayuran dapat dijadikan alternatif varian bakso di kalangan masyarakat Desa Payungan Kecamatan Kaliwungu Kabupaten Semarang.

Kami juga telah menyurvei penjual bakso di sepanjang Jl. Raya Ampel - Simo terdapat 10 penjual bakso, namun tidak satu pun yang menjual bakso berbahan dasar sayuran. Hal ini semakin mendorong kami untuk membuat varian bakso baru yang merupakan bakso yang terbuat dari campuran kedelai dan berbagai macam sayuran seperti wortel, kembang kol dan brokoli dengan aneka bentuk yang menarik.

Kedelai (Glysine max) merupakan sumber protein dan lemak nabati, oleh karena itu kami memilih bahan kedelai sebagai pengganti daging dalam campuran bakso dan harganya yang relatif terjangkau menjadi pertimbangan kami. Menurut Pangli (2014) tanaman kedelai merupakan sumber bahan pangan nabati dengan kandungan protein 35\%, lemak 18\%, karbohidrat 35\% dan air 8\%. Hal senada juga di sampaikan oleh Kusheryani (2006) bahwa kedelai merupakan salah satu tanaman golongan leguminosae yang menjadi komoditas tanaman terpenting kedua setelah padi. Kebutuhan akan kedelai di Indonesia dari tahun ke tahunterus meningkat baik sebagai akibat pertambahan jumlah penduduk maupun meningkatnya kebutuhan pangan serta industry (Jayasumarta, 2012). Tanaman kedelai ialah palawija yang kaya akan kandungan. Varietas tersebut termasuk kedalam jenis varietas genjah yang mempunyai keunggulan umurnya lebih pendek dari kedelai yang lain dan punya ukuran polong besar serta tingkat kematangan polong dan daun bersamaan (Prasetyo, 2014). Tanaman kedelai umumnya ditanam pada 
musim marengan yaitu suatu peralihan musim penghujan ke musim kemarau. Kedelai tergolong pada tanaman yang tidak tahan kekeringan dan kelebihan air (Nugraha, 2014). Sayuran yang kami pilih untuk bahan dasar bakso yaitu Wortel (Daucus carota), sayuran yang sering dikonsumsi oleh masyarakat, utamanya sebagai campuran dalam pembuatan sayur sop. Wortel mempunyai kandungan gizi yang sangat tinggi terutama kandungan beta karoten yang berfungsi menjaga kesehatan mata. Brokoli (Brassica oleracea var. Italica) dan kembang kol (Brassica oleracea var. Botrytis) adalah sayuran yang memiliki bentuk yang hampir sama, namun warnanya berbeda. Brokoli berwarna hijau sedangkan kembang kol berwarna putih kekuningan. Kedua sayuran ini memiliki kandungan antioksidan yang cukup tinggi berfungsi dalam mencegah penyakit kanker. Komposisi zat gizi kedelai wortel, brokoli, dan kembang kol dapat dilihat di Tabel berikut ini.

Tabel 2. Komposisi zat gizi kedelai kering, wortel, brokoli, dan kembang kol dalam 100 gram

\begin{tabular}{|c|c|c|c|c|c|}
\hline \multirow{2}{*}{ Komposisi } & \multirow{2}{*}{ Satuan } & \multicolumn{4}{|c|}{ Jumlah } \\
\hline & & Kedelai kering & Wortel & Brokoli & Kembang kol \\
\hline Protein & gram & 34,9 & 1,2 & 3,3 & 1,28 \\
\hline Lemak & gram & 18,9 & 0,3 & - & 0,1 \\
\hline Karbohidrat & gram & 34,8 & 9,3 & 5,5 & 5,8 \\
\hline Kalsium & milligram & 227,0 & 39,0 & - & 40,0 \\
\hline Fosfor & milligram & 585,0 & 37,0 & 76,0 & 26,0 \\
\hline Besi & milligram & 8,9 & 0,8 & 1,3 & 0,47 \\
\hline Vitamin A & SI & 110,0 & 1200,0 & $3.500,0$ & - \\
\hline Vitamin B1 & milligram & 1,07 & 0,06 & 10 & 0,061 \\
\hline Vitamin C1 & milligram & - & 6,00 & 118,0 & 36,6 \\
\hline Air & gram & 7,5 & 88,20 & - & - \\
\hline
\end{tabular}

Komposisi gizi yang lengkap dan harga yang murah menjadi alasan kami dalam memilih bahan sayuran yang digunakan dalam pembuatan bakso sehingga bakso tersebut menjadi salah satu pilihan menu sehat, bergizi dan mempunyai harga yang terjangkau bagi kalangan masyarakat luas

\section{Metode}

Dalam kegiatan pelatihan ini, timIbM membagi kader PKK Desa Payungan untuk pembuatan "BAKSO VEGETA". Dari 29 kader PKK Masing-masing kelompok terdiri dari 4-5 kader dalam setiap kelompok. Pengelompokan bertujuan supaya kinerja mereka lebih mudah jika dilakukan dengan anggota yang sudah dikenal dengan baik, selain itu diharapkan pula mereka dapat menumbuhkembangkan usaha ini di daerah mereka dan dapat bekerja sama mengelola usaha baru di sana dimulai dari kader PKK Desa Payungan. Instrumen pelaksanaan masing-masing kelompok tersebut diberikan sama proporsinya, sehingga memudahkan mereka untuk melakukan kegiatan. Setiap peserta pelatihan juga diharuskan untuk mengaplikasikan materi yang sudah diberikan timIbM, jadi tidak ada peserta yang tidak ikut terlibat. Semua peserta ikut terlibat dan masing-masing kelompok melakukan pembagian kerja sendiri di dalam kelompoknya. Beberapa tahapan yang dilakukan untuk memproduksi bakso adalah sebagai berikut.

Tabel 3. Metodelogi Pelaksanaan Kegiatan

\begin{tabular}{lllll}
\hline No & Materi & Metode & Evaluasi & Alokasi Waktu \\
\hline 1. & Pelatihan pembuatan bakso & $\begin{array}{l}\text { Ceramah } \\
\text { dan Praktik }\end{array}$ & Tanya jawab & 2x60 menit \\
2. & $\begin{array}{l}\text { Praktik pembuatan bakso oleh PKK } \\
\text { Ceramah } \\
\text { Desa Payungan Praktik }\end{array}$ & Tanya jawab & 2x60 menit \\
$\begin{array}{l}\text { Evaluasi dan tindaklanjut } \\
\text { pemanfaatan sayuran un } \begin{array}{l}\text { Ceramah } \\
\text { memproduksi bakso }\end{array}\end{array}$ & Tanya jawab & 2x60 menit \\
& & \\
\hline
\end{tabular}


Tabel 4. Pelaksanaan kegiatan pengabdian

\begin{tabular}{llll}
\hline No & Kegiatan & $\begin{array}{l}\text { Hari dan tanggal } \\
\text { kegiatan }\end{array}$ & Tempat Pelaksanaan \\
\hline 1. & Pelatihan pembuatan bakso & Selasa, 14 November & Rumah ketua PKK Desa Payungan \\
& 2017 & $\begin{array}{l}\text { Kecamatan Kaliwungu Kabupaten } \\
\text { Semarang }\end{array}$ \\
2. & $\begin{array}{l}\text { Praktik pembuatan bakso oleh PKK } \\
\text { Desa Payungan }\end{array}$ & Selasa, 21 November & $\begin{array}{l}\text { Kantor PKK Desa Payungan } \\
\text { Kecamatan Kaliwungu Kabupaten } \\
\text { Semarang }\end{array}$ \\
3. & $\begin{array}{l}\text { Evaluasi dan tindaklanjut } \\
\text { pemanfaatan sayuran untuk } \\
\text { memproduksi bakso }\end{array}$ & Jum'at, 1 Desember & $\begin{array}{l}\text { Rumah ketua PKK Desa Payungan } \\
\text { Kecamatan Kaliwungu Kabupaten } \\
\text { Semarang }\end{array}$ \\
\hline
\end{tabular}

\section{Hasil dan pembahasan}

Kegiatan ini dilaksanakan di 3 (tiga) lokasi yaitu: 1. Rumah Ketua PKK Desa Payungan Kecamatan Kaliwungu Kabupaten Semarang. 2. Kantor PKK PKK Desa Payungan Kecamatan Kaliwungu Kabupaten Semarang yang terletak di Balai Desa, 3. Laboratorium Gizi Universitas Ngudi Waluyo. Adapun tim pelaksana program pengabdian ini antara lain: 1. Ika Silfiana Arifatul Khoiriyah, M. Pd. (Ketua Tim Pelaksana), 2. Dyah Kartika Wening, S. Pd. (Anggota Tim Pelaksana). berikut:

Kegiatan yang dilakukan untuk mengatasi permasalahan yang dihadapi mitra adalah sebagai

a) Kegiatan yang dilakukan selama bulat Agustus sampai September 2017 meliputi:

1. Studi pustaka kandungan gizi dan manfaat sayuran serta cara pembuatan bakso

Studi Pustaka mengenai nilai gizi dan manfaat pengolahan sayuran serta cara pembuatan bakso dilaksanakan pada tanggal 29 Agustus 2017, pukul 09.00-14.00 WIB. Studi literatur dilaksanakan oleh tim melalui internet dan buku pustaka.

2. Rapat koordinasi awal dengan mitra PKK Desa Payungan Kecamatan Kaliwungu Kabupaten Semarang.

Rapat koordinasi awal dilaksanakan pada tanggal 3 dan 10 September 2017 pukul 14.00 WIB di rumah Ketua PKK Desa Payungan Kecamatan Kaliwungu Kabupaten Semarang. Koodinasi dilaksanakan oleh seluruh tim pengabdian masyarakat yang berjumlah 3 orang untuk menyampaikan bahwa proposal kegiatan yang diusulkan didanai sehingga Tim Pelaksana dan Mitra bisa bersamasama membuat rencana pelaksanaan kegiatan selanjutnya.

3. Uji coba/optimasi Tahap I Resep bakso

Resep bakso yang akan dipraktekkan dalam pelatihan terlebih dahulu dicoba agar diperoleh formula resep yang baik dengan hasil prosuk yang baik. Pelaksanaan uji coba resep dilakukan di laboratorium gizi Universitas Ngudi Waluyo pada tanggal 13 September 2017 pukul 10.00 WIB. Hasil pembuatan bakso belum cukup memuaskan secara organoleptis sehingga harus dicoba lagi. Namun untuk rendeman yang dihasilkan sudah cukup memuaskan sehingga jika dijual di masyarakat maka masih cukup dijangkau secara ekonomis.

b) Kegiatan yang dilakukan selama bulan Oktober-November 2017 meliputi:

1. Uji coba resep bakso Tahap II

Tindak lanjut Uji coba resep bakso Tahap II dilaksanakan pada tanggal 26 Oktober 2017 pukul 10.00-14.00 di Laboratorium Gizi Universitas Ngudi Waluyo. Dari resep yang dicoba bakso telah berhasil dengan baik dengan rasa dan bentuk yang memuaskan dan menggugah selera.

2. Mencetak stiker kemasan bakso

Stiker kemasan digandakan sebelum dilaksanakan kegiatan pelatihan. Penggandaan dilaksanakan pada tanggal 1 November 2017.

3. Koordinasi dan diskusi dengan ketua PKK Desa Payungan Kecamatan Kaliwungu Kabupaten Semarang

Koordinasi dilaksanakan pada tanggal 5 November 2017 pukul 14.00-16.00 WIB di rumah ketua PKK Desa Payungan Kecamatan Kaliwungu Kabupaten Semarang. Diskusi dengan ketua dan pengurus PKK Desa Payungan untuk teknis pelaksanaan pelatihan dapat ditarik hasil bahwa pelatihan dilakukan di rumah ketua PKK Desa Payungan Kecamatan Kaliwungu Kabupaten Semarang.

4. Persiapan Pelatihan (Pengadaan Bahan, dll)

Pembelian bahan dilaksanakan pada tanggal 7 November 2017 oleh ketua Tim dalam kegiatan IbM bakso pukul 09.00-12.00 WIB. Kegiatannya meliputi: a. Pembuatan undangan pelatihan dan 
penyampaian ke Peserta Pelatihan, Pada tanggal 9 November pulul 14.00 WIB dilaksanakan kunjungan ke Mitra yaitu ketua PKK Desa Payungan Kecamatan Kaliwungu Kabupaten Semarang untuk menyampaikan undangan kegiatan pelatihan yang akan dilaksanakan pada tanggal 14 dan 12 November 2017 pukul 14.00 WIB, b. Penggandaan materi pelatihan, Penggandaan materi pelatihan disiapkan pada tanggal 11 November 2017 oleh ketua dan anggota pelaksana kegiatan, dan c. Pelaksanaan kegiatan pelatihan di PKK Desa Payungan Kecamatan Kaliwungu Kabupaten Semarang.

1) Kegiatan pelatihan nantinya akan dilaksanakan pada tanggal 14 November 2017 di rumah ketua PKK Desa Payungan Kecamatan Kaliwungu Kabupaten Semarang pukul 14.00-16.30 WIB. Kegiatan nantinya akan dihadiri beberapa Kader anggota PKK Desa Payungan Kecamatan Kaliwungu Kabupaten Semarang. Setiap peserta mengikuti kegiatan dengan antusias hingga acara selesai dan termotivasi untuk memproduksi sendiri. Kegiatan yang dilaksanakan dengan terlebih dahulu dibuka oleh ketua PKK Desa Payungan Kecamatan Kaliwungu Kabupaten Semarang. Acara inti kegiatan pelatihan yang akan dilakukan adalah penyampaian materi manfaat dan nilai gizi sayuran dan pelatihan/praktek membuat bakso .

2) Kegiatan pelatihan nantinya akan dilaksanakan pada tanggal 21 November 2017 di kantor PKK Desa Payungan Kecamatan Kaliwungu Kabupaten Semarang pukul 14.00-16.30 WIB. Kegiatan nantinya akan dihadiri beberapa orang anggota PKK Desa Payungan Kecamatan Kaliwungu Kabupaten Semarang. Kegiatan yang dilaksanakan dengan terlebih dahulu dibuka oleh Kepala Desa Payungan kemudian dilanjutkan dengan peresmian dan syukuran Kantor baru PKK Desa Payungan Kecamatan Kaliwungu Kabupaten Semarang. Acara inti kegiatan pelatihan yang akan dilakukan praktek bersama membuat bakso. Setiap peserta diharapkan mengikuti kegiatan dengan antusias hingga acara selesai dan termotivasi untuk memproduksi sendiri sayuran yang bernilai gizi tinggi.

Dengan demikian diharapkan dari kegiatan pengabdian pada Masyarakat pada Skim Ipteks bagi Masyarakat (IbM) anggaran 2017 ini bermanfaat dalam pengolahan sayuran menjadi prosuk yang bernilai gizi tinggi untuk kesehatan dan secara ekonomis menjadi produk dengan nilai jual lebih tinggi. Pemberian pelatihan diharapkan menjadi proses penyaluran Ilmu Pengetahuan dan Teknologi dalam pemanfaat sayuran sehingga bermanfaat bagi kesehatan, tidak dibuang sia-sia, dan mejadi produk mengkatkan nilai jual lebih tinggi.

Dalam kegiatan pelatihan ini, timIbM membagi kader PKK Desa Payungan untuk pembuatan "BAKSO VEGETA". Dari 29 kader PKK Masing-masing kelompok terdiri dari 4-5 kader dalam setiap kelompok. Pengelompokan bertujuan supaya kinerja mereka lebih mudah jika dilakukan dengan anggota yang sudah dikenal dengan baik, selain itu diharapkan pula mereka dapat menumbuhkembangkan usaha ini di daerah mereka dan dapat bekerja sama mengelola usaha baru di sana dimulai dari kader PKK Desa Payungan. Instrumen pelaksanaan masing-masing kelompok tersebut diberikan sama proporsinya, sehingga memudahkan mereka untuk melakukan kegiatan. Setiap peserta pelatihan juga diharuskan untuk mengaplikasikan materi yang sudah diberikan timIbM, jadi tidak ada peserta yang tidak ikut terlibat. Semua peserta ikut terlibat dan masing-masing kelompok melakukan pembagian kerja sendiri di dalam kelompoknya. Tahap-tahap yang dilaksanakan.

Perlengkapan Produksi yang diperlukan antara lain: a.Gerobak, b. Kompor, c. Tabung gas, d. Panci besar, e. Irus, f. Saringan, g. Pisau, h. Talenan, i. Blender, j. Wajan, k. Cobek, l. Solet, m. Toples, n. Rak plastic, o. Jepit makanan, p. Gunting, q. Piring, r. Nampan, s. Ember, t. Garpu, u. Sendok, v. Mangkok, w. Gelas, x. Tempat krupuk, y. Tempat saos, z. Tempat sambel, å. Tempat kecap, ä. Tempat tusuk gigi, ö. Tempat tisu, aa. Tempat sampah, bb. Daftar menu, cc. Plastik pembungkus

\section{Pembuatan "BAKSO VEGETA"}

a. Proses Pembuatan "BAKSO VEGETA"

Tumbuk garam, gula pasir, merica, kemiri, bawang putih, hingga bumbu halus dan tercampur rata. Campur kedelai yang sudah dihaluskan dengan tepung terigu dan tepung kanji dengan bumbu yang sudah halus tadi hingga menjadi adonan yang tercampur rata. Diamkan adonan selama \pm 30 menit agar pulen. Sambil menunggu, cuci sayuran kemudian potong sayuran (wortel, brokoli, kembang kol) dan blender sayuran hingga halus secara terpisah. Campurkan adonan dengan sayuran yang sudah diblender. Setelah tercampur rata cetak dengan bentuk yang diinginkan, kemudian masukkan hasil cetakan kedalam rebusan air mendidih. Rebus bakso selama \pm 15 menit, setelah bakso matang tiriskan.

b. Proses Pembuatan Kuah

Dalam pembuatan kuah bakso ini kami menggunakan campuran bahan hewani. Panaskan air sebanyak \pm 10 liter , masukkan ayam, setelah mendidih diamkan selama 10 menit kemudian tiriskan. Sambil menunggu air mendidih siapkan bawang putih yang sudah dikupas dan dicuci bersih, garam, merica, gula kemudian tumbuk sampai halus. Bumbu yang sudah ditumbuk kemudian ditumis sampai 
harum. Masukkan dan aduk bumbu yang telah ditumis tadi ke dalam air yang sedang direbus dan tunggu hingga air mendidih.

c. Proses pembuatan bahan pendukung

Pembuatan bawang goreng

Kupas bawang merah kemudian cuci bersih, iris bawang merah menjadi tipis-tipis, panaskan minyak goreng, kemudian goreng bawang merah sampai berwarna kuning keemasan. Tiriskan bawang goreng di atas kertas agar minyak terserap sehingga bawang goreng bertahan renyah.

Pembuatan sayur pendukung

Bersihkan sawi, wortel, brokoli, kembang kol, daun bawang, daun seledri. Rebus sebentar sayuran tersebut kemudian tiriskan.

\section{Simpulan dan saran}

Kegiatan pengabdian kepada masyarakat melalui skim Hibah Iptek bagi Masyarakat sumber dana LP2M Universitas Ngudi Waluyo tahun 2017 yang hasilnya berupa pelatihan untuk kegiatan IbM di Mitra PKK Desa Payungan Kecamatan Kaliwungu Kabupaten Semarang. Dalam kegiatan pelatihan IbM ini dihadiri anggota di Mitra PKK Desa Payungan Kecamatan Kaliwungu Kabupaten Semarang yang diikuti dengan antusias sampai acara selesai dan termotivasi untuk memproduksi sendiri. Dengan demikian diharapkan kegiatan ini bermanfaat dalam pengolahan sayuran menjadi produk yang lebih bernilai tinggi untuk kesehatan dan secara ekonomi menjadi produk dengan nilai jual lebih tinggi. Pemberian pelatihan diharapkan menjadi proses penyaluran Ilmu Pengetahuan dan Teknologi dalam pengolahan sayuran sehingga bermanfaat bagi kesehatan, tidak dibuang sia-sia, dan menjadi produk meningkatkan nilai jual lebih tinggi.

Perlu adanya evaluasi berkesinambungan dalam memonitor hasil kegiatan ini untuk menjadi langkah dalam pengolahan sayuran sehingga bermanfaat bagi kesehatan, tidak dibuang sia-sia, dan menjadi produk yang dapat meningkatkan nilai jual lebih tinggi melalui peningkatan produksi sakala industri rumah tangga sehingga diharapkan dapat meningkatkan pendapatan keluarga masyarakat di Desa Payungan Kecamatan Kaliwungu Kabupaten Semarang.

\section{Daftar Rujukan}

Adiningsih, S. J. dan Rochayati. (1988). Peranan Bahan Organik dalam Meningkatkan Efisiensi Pupuk dan Produktivitas Tanah. p 161-181. Dalam M. Sudjadi et. al. (eds). Bogor: Prosiding Lokakarya Nasional Efisiensi Pupuk,

Adisasmito, Wiku. (2008). Sistem Kesehatan. Jakarta: Raja Grafindo Persada.

Almatsier, Sunita. (2001). Prinsip Dasar Ilmu Gizi. Jakarta: Gramedia Pustaka Utama.

Baliwati, Yayuk Farida. (2004). Pengantar Pangan dan Gizi. Jakarta: Penebar Swadaya.

Creswell, John W. (2010). Research Design Pendekatan Kualitatif. Kuantitatif. dan Mixed. Yogyakarta: Pustaka Pelajar.

Doll JP, Orazem F. (1984). Production Economics Theory with Applications. New York: John Wiley and Sons.

Jayasumarta, Darmawati. 2012. Pengaruh Sistem Olah Tanah Dan Pupuk P Terhadap Pertumbuhan Dan Produksi Tanaman Kedelai (Glycine max L. Merril). Jurnal Ilmu Pertanian, Volume 17, No 3.

Joesron, Suhartati. dan Fathorrozi. (2003). Teori Ekonomi Mikro. Jakarta: Salemba Empat.

Kementerian Pertanian Republik Indonesia. (2015). Rencana Strategis Kementrian Pertanian tahun 20152019. Jakarta: Kementrian Pertanian Republik Indonesia.

Kusheryani, Ina dan Sandra Arifin Aziz. 2006. Pengaruh Jenis Tanaman Penolak Organisme Pengganggu Tanaman terhadap Pertumbuhan dan Produksi Tanaman Kedelai (Glycine max (L.) Merr) yang Diusahakan Secara Organik. Jurnal Agronomi Indonesia, Vol. 34, No. 1. 
Lipsey. R. (1995). Pengantar Mikroekonomi. Jakarta: Binarupa Aksara.

Nugraha,Yoga Sasmita dkk. 2014. Pengaruh Interval Waktu Dan Tingkat Pemberian Air Terhadap Pertumbuhan Dan Hasil Tanaman Kedelai (Glycine max (L) Merril). Jurnal Protan, Vol.2, No.7.

Nerty Soverda. 2007. Pengaruh Berbagai Kadar Air Tanah Terhadap Pertumbuhan dan Hasil Tanaman Kedelai yang Diberi Mikoriza Vesikular Arbuskular. Jurnal Agronomi. Vol. 11 no. 2.

Nurhayati. 2009. Pengaruh Cekaman Air Pada Dua Jenis Tanah Terhadap Pertumbuhan dan Hasil Kedelai (Glycine max (L.) Merril). Jurnal Floratek. Vol. 4, Hal. 55-64.

Putong, I. (2003). Pengantar Ekonomi Mikro dan Makro (Edisi 2). Jakarta: Ghalia Indonesia.

Pangli, Marthen. 2014. Pengaruh Jarak Tanaman Terhadap Pertumbuhan Dan Hasıl Kedelai (Glycine max L Merril). Jurnal Agro Pet, Vol. 11, Nomor 1.

Prasetyo,Rizky Adie dkk. 2014. Pengaruh Sistem Olah Tanah Dan Berbagar Mulsa Organık Pada Pertumbuhan Dan Hasıl Tanaman Kedelaı (Glycine Max (L.) Merr.) Var. Grobogan. Jurnal Produksı Tanaman, Vol. 1, No. 6.

Rusono, Nono dkk. (2014). Pencana Pembangunan Jangka Menengah Nasional (RPJMN) Bidang Pangan dan Pertanian 2015-2019. Jakarta: Direktorat Pangan dan Pertanian..

Sugiyono. (2011). Metode Penelitian Kuantitatif. Kualitatif dan R\&D. Bandung: Alfabeta

Suhartono. 2008. Pengaruh Interval Pemberian Air Terhadap Pertumbuhan dan Hasil Tanaman Kedelai (Glycine max (L) Merril) Pada Berbagai Jenis Tanah. Jurnal Embryo, Vol, 5, No. 1.

Totok Agung. 2004. Analisis Efisiensi Serapan N, Perumbuhan dan Hasil Beberapa Kultivar Kedelai Unggul Baru dengan Cekaman Kekeringan dan Pemberian Pupuk Hayati. Jurnal Agrosains, Vol. 6, No. 2, Hal. 70-74

Zen, I., M. Kamal, M. S. Hadi dan E.Pramono. 1993. Tanggapan Beberapa Varietas Kedelai (Glycine max (L.) Merr) Terhadap Jumlah Pemberian air. Jurnal Penelitian Pengembangan Wilayah Kering Vol. 12, Hal. 56-61. 